\title{
Speleoseismology and palaeoseismicity of Benis Cave (Murcia, SE Spain): coseismic effects of the 1999 Mula earthquake $\left(m_{b} 4.8\right)$
}

\author{
R. PÉREZ-LÓPEZ1*, M. A. RODRÍGUEZ-PASCUA , J. L. GINER-ROBLES², \\ J. J. MARTÍNEZ-DÍAZ ${ }^{3}$, A. MARCOS-NUEZ ${ }^{4}$, P. G. SILVA ${ }^{5}$, \\ M. BEJAR ${ }^{2} \&$ J. P. CALVO ${ }^{1}$
}

${ }^{1}$ Área de Riesgos Geológicos, Instituto Geológico y Minero de España, C/Ríos Rosas 23, Madrid 28003, Spain

${ }^{2}$ Dpto. de CCAA y RRNN, Universidad CEU San Pablo, Madrid, Spain

${ }^{3}$ Dpto. de Geodinámica, Facultad de Ciencias Geológicas, Universidad Complutense de Madrid, Spain

${ }^{4}$ Grupo Especial de Rescate en Altura, GERA, Cuerpo de Bomberos de la Comunidad de Madrid, Spain

${ }^{5}$ Dpto. de Geología, Universidad de Salamanca, Escuela Politécnica Superior de Ávila, Spain

*Corresponding author (e-mail: r.perez@igme.es)

\begin{abstract}
This work describes the coseismic ceiling block collapse within Benis Cave (2213 m; Murcia, SE Spain), associated with the 1999 Mula earthquake ( $m_{b} 1 / 44.8$, MSK VII). The collapse occurred at $2156 \mathrm{~m}$ into the Earthquake Hall, and as a consequence one small gallery became blind. We studied the geology, topography and active tectonic structures relevant to the cave. In addition, we carried out a seismotectonic analysis of the focal mechanism solutions, and also a fault population analysis on slickensides measured in fault planes in the cave. The stress and strain regime is interpreted as being congruent with the palaeoseismic evidence, and agrees with the fault kinematics established for cave galleries developed within fault planes and growth anomalies of coral flowstone. Our analysis suggests that one active segment (NNE- SSW) determined the morphology and topography of the Benis Cave, where strong to moderate palaeoearthquakes (6 :.:; M .:.; 7) took place. As a consequence of this intense seismic activity a small gallery collapsed. A new palaeoseismic structure, or seismothem, has been recognized, namely the effect of palaeoearthquakes affecting the pattern of development of the spatial coral flowstone distribution located at the bottom of the cave.
\end{abstract}

Endokarstic terrains represent favourable environments for the preservation of palaeoseismic evidence associated with shaking and faulting produced by earthquakes (Postpischl et al. 1991; Gilli et al. 1999; Cadorin et al. 2001; Kagan et al. 2005). This terrain results from a delicate equilibrium between dissolution- precipitation processes affecting soluble rocks (carbonates, evaporites, lime sandstones, etc.). The equilibrium reflects the climatic conditions of the area (atmospheric content of $\mathrm{CO}_{2}$, temperature, humidity, etc.), the tectonic setting of the rock mass (fault and joint geometry), the hydrogeologic constraint (phreatic level) and the chemical composition of the source area (water and rock).

A rhythmic and constant velocity of the dissolution-precipitation rate controls the genesis of the endokarst (Bauer et al. 2003). This fact implicates quiet periods, slow variations of the phreatic level and the presence of permanent water-sheets and pools. In this context, the occurrence of earthquakes perturbs the short-term dynamic of the karst, for example causing broken and tilted speleothems, growth anomalies in carbonate layers and block collapses (Gilli 2005).

Speleoseismology represents a new branch of the palaeoseismology that analyses the earthquake record in caves (Kagan et al. 2005; Becker et al. 2006). Earthquake shaking and faulting in caves can be deduced from two different features.

(A) Destructive features: broken speleothems, fallen stalactites, severed stalagmites (Kagan et al. 2005), block collapse (incasion), blind galleries, deformed cave sediment structures and coseismic fault displacement affecting cave deposits. These types of features are classified as seismothems (Delaby 2001). 
(B) Constructive features: growth anomalies in carbonate layers and sudden changes in the pattern of precipitation layers produced by tilting or sharp migration of the phreatic surface.

However, processes other than tectonic shaking and faulting may produce similar structures, either destructive and/or constructive, e.g. creep movement of saturated silt sediments, ice filling in caves (glacitectonics), gravity failure and thermohydromecanics (Gilli 2005; Becker et al. 2006).

Previous work has identified and characterized active faults from the analysis of coseismic effects in caves, assuming a relationship between earthquakes and cave dynamics (e.g. Gilli et al. 1999). These authors concluded that one earthquake of 5.2 magnitude was responsible for breaking several soda-straw structures located at the Saint-Paul-de-Fenouillet caves (eastern Pyrenees). The main orientation of these broken soda-straws was east- west, agreeing with the proposed seismogenic fault, the North Pyrenean Fault. Gilli et al. (1999) also observed previous palaeoseismic damage. Gilli (2005) and Becker et al. (2006) pointed out the scarcity of direct observation of coseismic earthquake damage in caves.

The main question regarding speleoseismology is the speculative relationship between the endokarst dynamic and the earthquake effect. Accordingly, we propose a protocol for the first approach to the relationship between active faults and the long-term evolution of speleothems:

(1) detailed description of the karst dynamic: the cave topography, tube sections, geology, phreatic level evolution and principal speleothems;

(2) systematic description of seismothems: destructive and constructive features;

(3) a complete seismotectonic analysis: mapping of active faults, Quaternary sediments, study of focal mechanism solutions of instrumental earthquakes (located at the proximity of ca. $50 \mathrm{~km}$.), historical seismic databases, palaeoseismic evidence and tectonic geomorphology studies near to the cave;

(4) numerical dating: ( $\mathrm{U}-\mathrm{Th}$ series) age of the structures to correlate with the time of occurrence of seismic events in the area (taken from seismic catalogues or palaeoseismic dating in active faults close to the cave) (Kagan et al. 2005; Gilli 2005).

In this work we present the first conclusion obtained from the morphotectonic and seismotectonic analysis of Benis Cave, in order to provide new descriptions of structures formed during an instrumental seismic event. In addition, a new type of palaeoseismic feature or seismothem - a migrating coral flowstone - may be used to identify and quantify at least two palaeoearthquakes.

Benis Cave, located in a Palaeocene to early Eocene carbonate massif in the Prebetic Zone of the Betic Cordillera, suffered a massive collapse of blocks at a depth of $2156 \mathrm{~m}$, coeval with the 1999 Mula earthquake $\left(m_{b} 4.8\right)$. From this earthquake several blocks larger than $1 \mathrm{~m}^{3}$ collapsed in a small gallery. These observations encouraged us to study the morphology and structure of this cave in detail. This study provided several structures that may be interpreted as palaeoseismic evidence.

The geological mapping of the study area (Jerez-Mir et al. 1972) shows the existence of a NNE-SSW strike-slip fault with normal component, which determines the morphostructure and topography of the cave. This fault appears within the cave, and in the collapsed gallery with impressive slickensides on the fault plane. We performed a kinematic analysis of these slickensides, and have compared the results with the present stress field responsible for the recent seismicity in the area. Hence, focal mechanism solutions were also analysed.

Antonio Salmerón, President of the Murcian Federation of Speleology (Spain) and topographer of the cave, climbed down to the abyss a few days after the Mula earthquake. From his observations, and the original topography, he concluded that one gallery and a small cave room $(2156 \mathrm{~m})$ had collapsed during the main shaking event of the earthquake. At this location in the cave we measured striations on fault planes to obtain the kinematic model of the fault movement, in order to make comparisons with focal mechanism solutions of the Mula earthquake.

\section{Geographic location and geology of the cave}

Benis Cave is located within the province of Murcia (SE Spain) (Fig. 1), close to the border with the province of Albacete, $10 \mathrm{~km}$ SE of Cieza Town. The UTM $(30 N)$ coordinates are X 645,220, Y 4,243,248 and Z $405 \mathrm{~m}$ high.

Benis Cave is developed within a MesozoicPalaeocene-Early Eocene carbonate massif of the Internal Prebetic autochthonous unit of the Betic Cordillera (Fig. 1) (Jerez-Mir et al. 1972). This massif consists of an anticline affecting deposits from Upper Cretaceous limestone (Caenomanian) to Eocene massive limestone. This anticline is flanked by synclines filled by Tortonian and Quaternary deposits (Fig. 2a, c).

The stratigraphic sequence of Benis Cave is composed of two principal units (Jerez-Mir et al. 1972): (1) concordant Cretaceous limestone and (2) Tertiary massive carbonates (Fig. 2b), also concordant with the Upper Cretaceous. The Cretaceous 


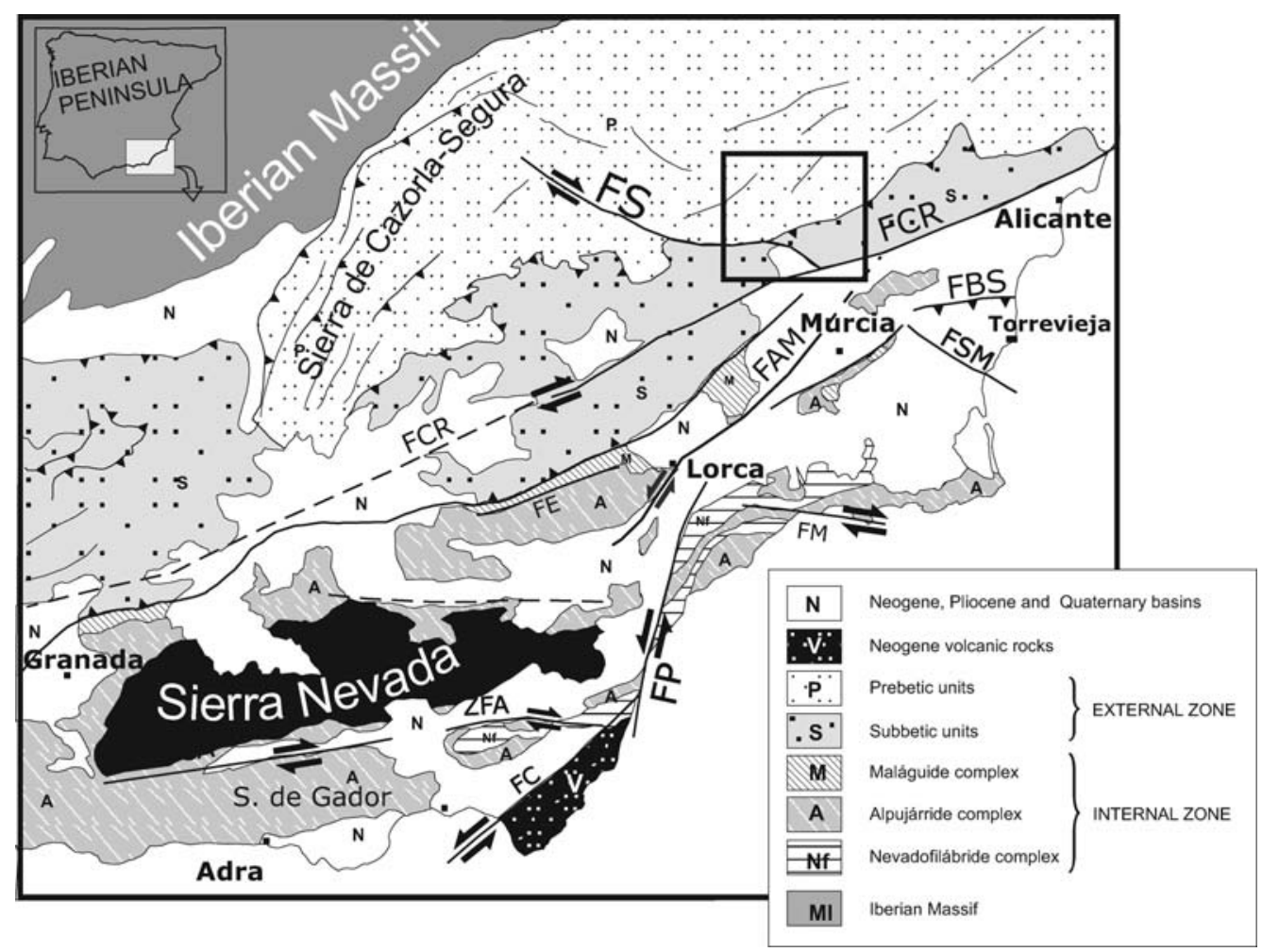

Fig. 1. Geographical location and major geological units of Benis Cave (black rectangular area). Major active faults of the area are indicated: FAM, Alhama-Murcia Fault; FBS, Bajo Segura Fault; FC, Carboneras Fault; FCR, Crevillente Fault; FE, Las Estancias Fault; FM, Las Moreras Fault; FP, Palomares Fault; FS, Socovos-Calasparra Fault; FSM, San Miguel Fault; ZFA, Alpujarras Fault.

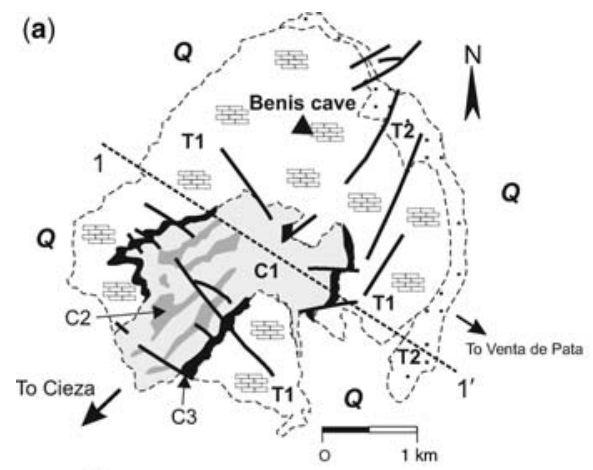

(c) 1 (b)

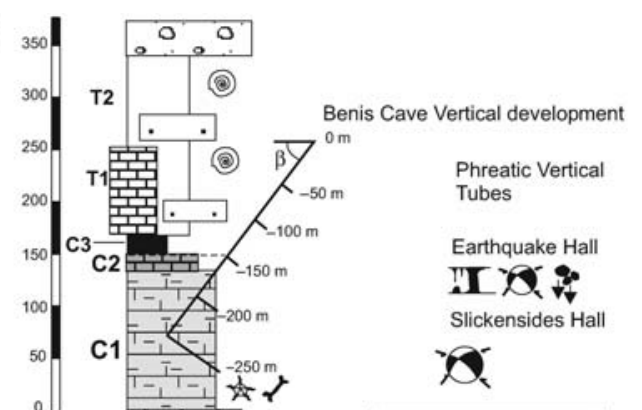

Legend Q. Kinematic grooves \$t Collapsed blocks II Dripstones - Globigerinas ts Equino.

Mammals

Fig. 2. (a) Geological sketch of Benis Cave. Key: C0, Cretaceous carbonate; C1, massive Upper Cretaceous Dolomite; C2, concordant massive white limestone; C3, marls and marly limestone; T1, Tertiary massive carbonate; T2, Tertiary. (b) Detailed stratigraphic log of the geology of Benis Cave. Kinematic data and earthquake evidence appear below c. $156 \mathrm{~m}$. (c) Cross section $1-1^{0}$ of the geological map (a). Benis Cave is located in a dome-shaped anticline (after Jerez-Mir et al. 1972). 
sequence is formed by $40 \mathrm{~m}$ of massive dolomite (Fig. 2b, C1), $20 \mathrm{~m}$ of massive white limestone with scarce fauna (e.g. Equinocorix vulgaria) (Fig. 2b, C2) and $25 \mathrm{~m}$ of white marls and marly limestone with globigerinas (Fig. 2b, C3). Tertiary carbonates are almost $150 \mathrm{~m}$ in width (Fig. 2b, T1).
The vertical topographic section of Benis Cave is developed to a depth of $c .213 \mathrm{~m}$, conforming to a quasi-vertical cave (Fig. 3). The surface of the cave begins with a small and narrow window section to the Railing Handy (after Ferrer 2004). At this location there appears a sequence of

\section{VERTICAL TOPOGRAPHY}
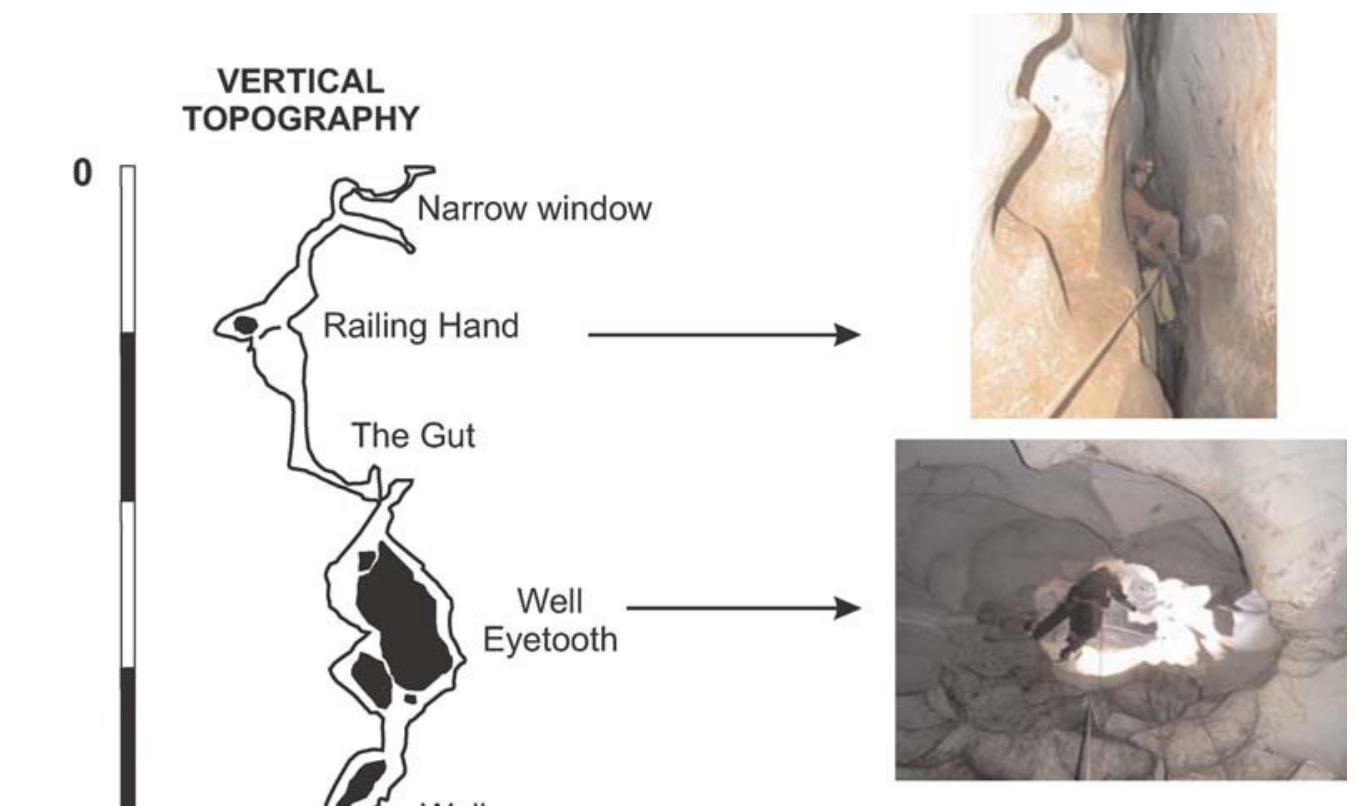

Well
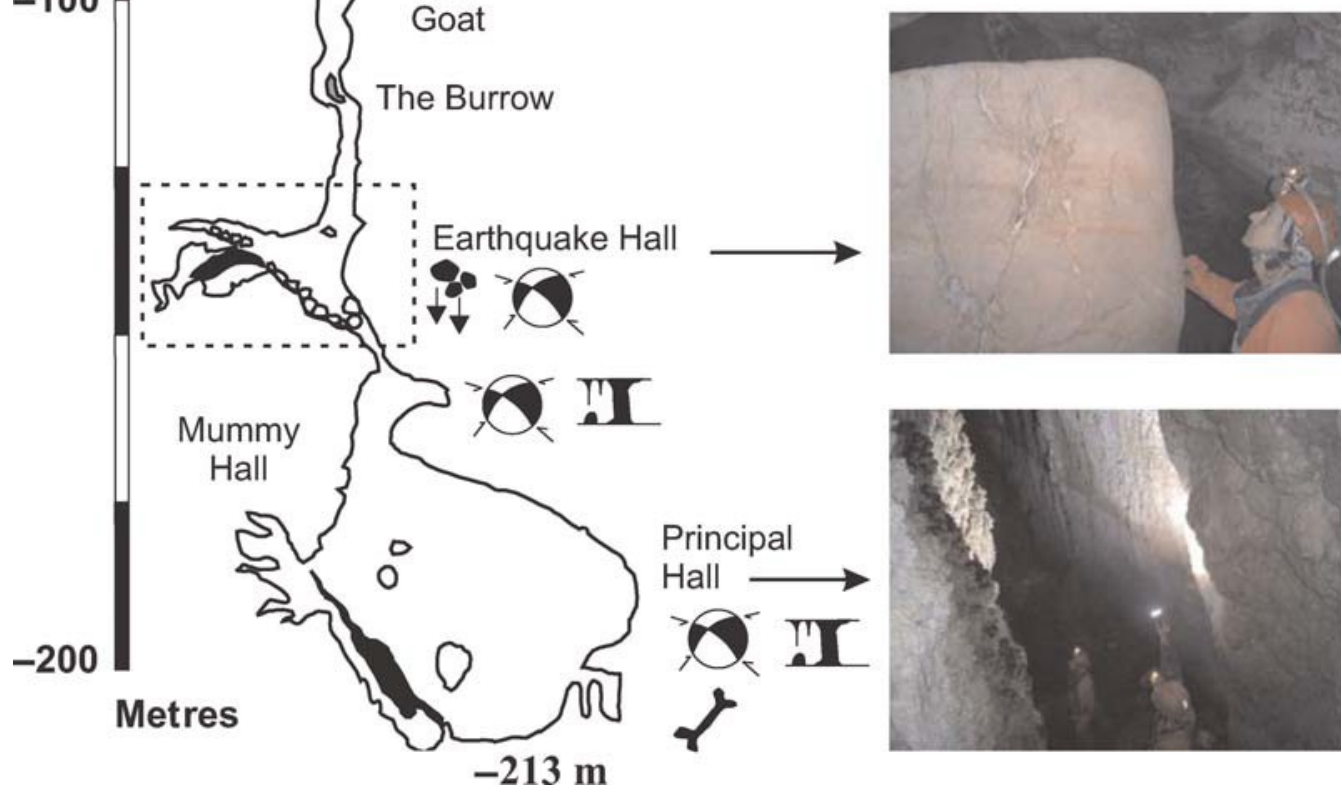

Fig. 3. Topographic sketch of Benis Cave (after Ferrer 2004). Symbols are described in the legend of Figure 2. See text for further explanation. 
various deep wells, affecting the Tertiary limestone (Gut Gallery, Eye-tooth Well, Goat Well and Burrow Gallery) (Figs 2 and 3). These galleries are phreatic tubes, eroded and showing great scallops (metric size). The last well ends in the so-called Chaos Hall (c. $156 \mathrm{~m})$ and a Deep Well head. It is in this part of the cave that the ceiling collapsed as a result of the Mula earthquake (1999). For this reason the collapsed gallery was renamed the Earthquake Hall (A. Salmerón, pers. comm.) (Fig. 3). The bottom of Benis Cave is the Principal Hall (Fig. 3), developed within a fault plane, and at its bottom small relict pools appear. This cave is preserved as an outcrop of Tertiary macro-mammals, containing bones of Felix (Lynx) spelaea and Ursus spelaea, covered by a thin carbonate sheet.

\section{Palaeoseismic study}

\section{Earthquake Hall (2156 m)}

Earthquake Hall (formerly Chaos Hall) exhibits several blocks from different collapses of the ceiling (Fig. 3) at this section of the cave. After the Mula earthquake, one small gallery collapsed, and new blocks appeared in the bottom of this hall. Based on a speleological survey, we reported great marl blocks with extensional calcite veins (Fig. 3) and fault breccia at this level (Fig. 4). These blocks range between $1 \mathrm{~m}^{3}$ to centimetric size, although a systematic analysis of the size distribution is needed to quantify a relationship between the collapse and the earthquake event. Both halls developed coincidently with the Upper Cretaceous contact between limestone and marls (Figs 3 and 4).

Several slickensides were measured on fault planes within the Earthquake Hall (Fig. 5a), and we used these data to obtain the strain field associated with these faults.

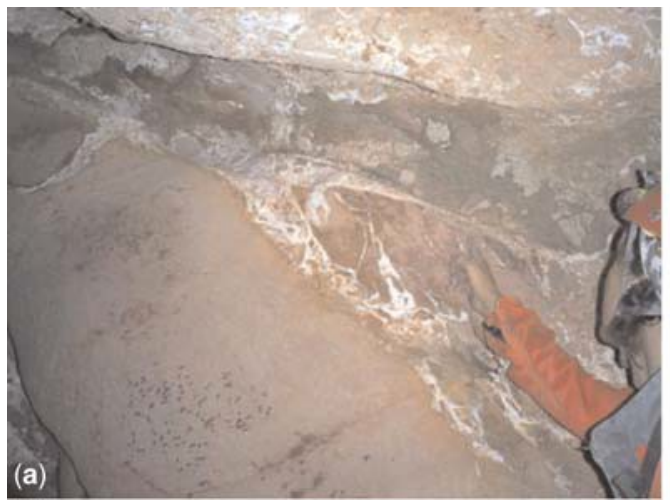

The Earthquake and Chaos Halls show poor decoration development and small calcite concretions without great speleothems. From the Chaos Hall to the bottom of the cave the Deep Well is developed along a fault plane (orientated NNE- SSW), with a vertical topographic section of a phreatic tube. This tube is tilted according to the dip of the fault $(758 \mathrm{NW})$. The decoration on both sides of the fault plane is different. The footwall exhibits flowstone and carbonate corals (pop-corn), whereas small stalactites (centimetric size) decorate the hanging wall. We have interpreted this fact to mean that the water-sheet flux is dominant, with the precipitation of thin laminated carbonates on the surface. In contrast, the hanging wall is decorated with dripstone structures (stalactites). The length of the fault plane reaches more than $80 \mathrm{~m}$ (Fig. 5b).

\section{Principal Hall (2213 m)}

The morphology of this hall is controlled by the NNE-SSW fault plane dipping 758 to the east (Fig. 5b), with dip-slip striations $(.70 \mathrm{~cm}$ long.). These slickensides are analysed in the next section.

Coral flowstone (pop-corns) of centimetric size decorates the dip-slip plane of the hall. We have interpreted the spatial distribution of three coral structures in relation to potential palaeoearthquakes (Fig. 6), and suggest a sudden migration of the coral flowstone towards the SW (Fig. 6, p1, p2 and p3). This pattern was deduced from the apical point migration of the coral flowstone towards the SW. We speculate that episodic movements of the fault, due to at least two potential palaeoearthquakes, displaced the source of water flow responsible of the coral precipitation (Fig. 7).

Bearing in mind that the fault plane is striated, we can reconstruct the kinematics of this fault.

Fig. 4. (a) Detailed photograph of the contact between the Tertiary limestone (T1) and Upper Cretaceous marls (C3), within the Earthquake Hall of Benis Cave $(2156 \mathrm{~m})$. The contact exhibits a fault breccia. See Figure 2 for the stratigraphic sequence of the cave. (b) Interpretation of the contact. 

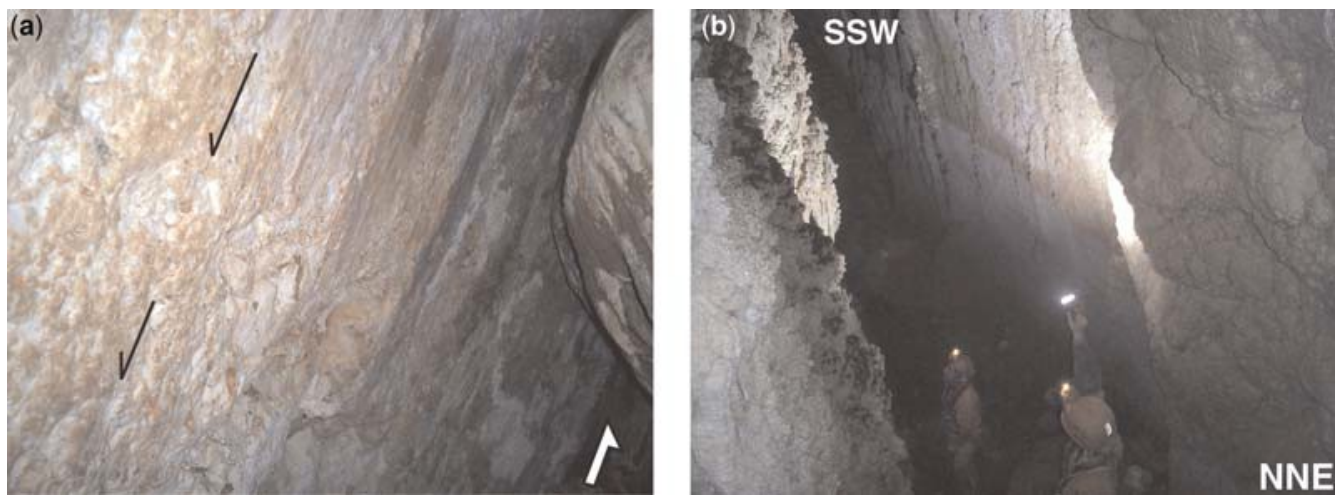

Fig. 5. Photographs of the fault plane showing slickensides (from $2156 \mathrm{~m}$ to the bottom of the cave). (a) White arrow indicates the movement direction of the uplifted block. (b) Fault plane of the bottom of the cave with the hanging wall covered by dripstones, developed across large slickensides.

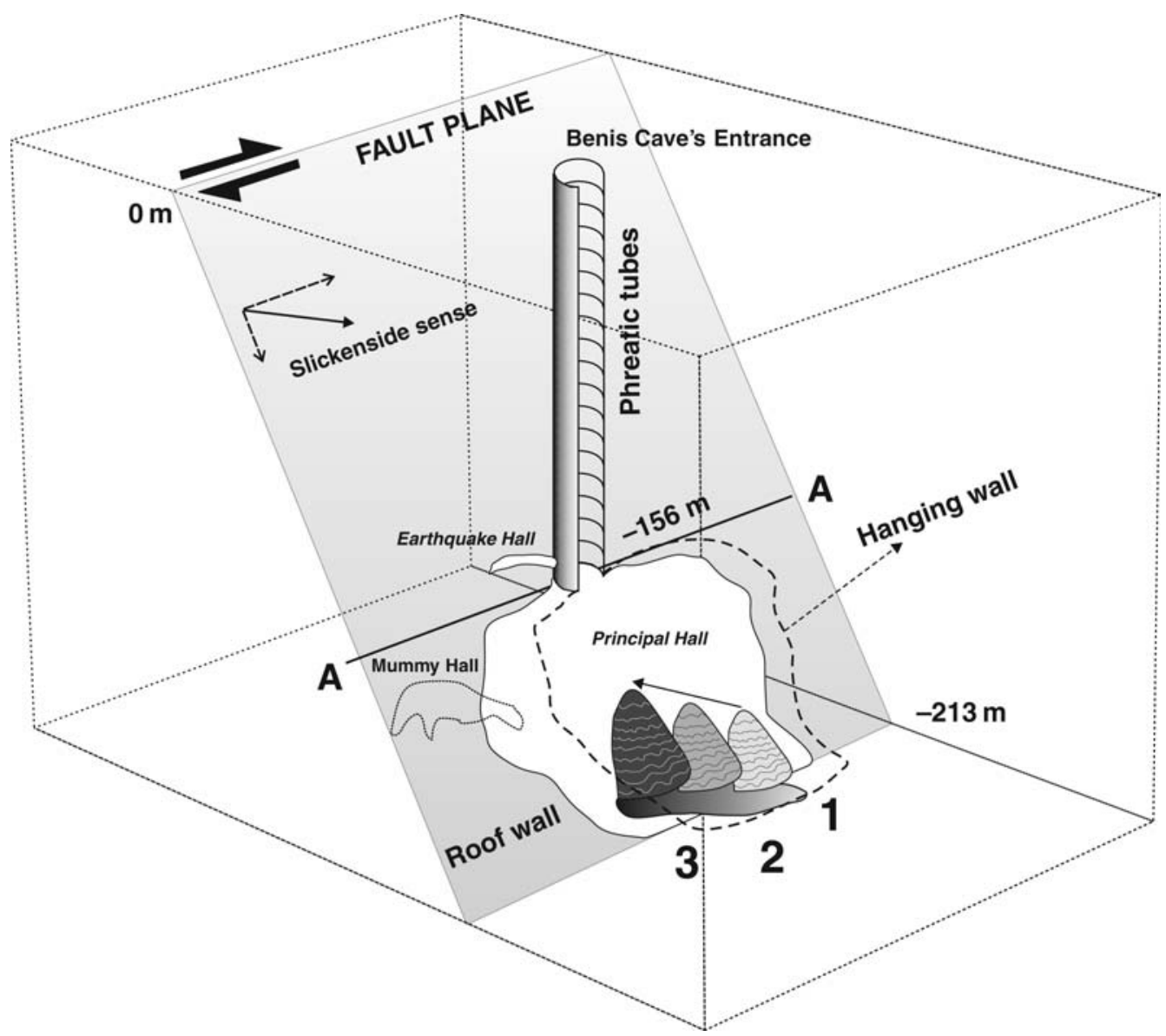

Fig. 6. Block diagram showing the spatial coral flowstone distribution on the footwall. From the Earthquake Hall to the bottom, the cave is determined by faults, with a theoretical migration of the coral flowstone on the footwall, according to the sinistral component of the oblique normal fault. 
(a)

a)
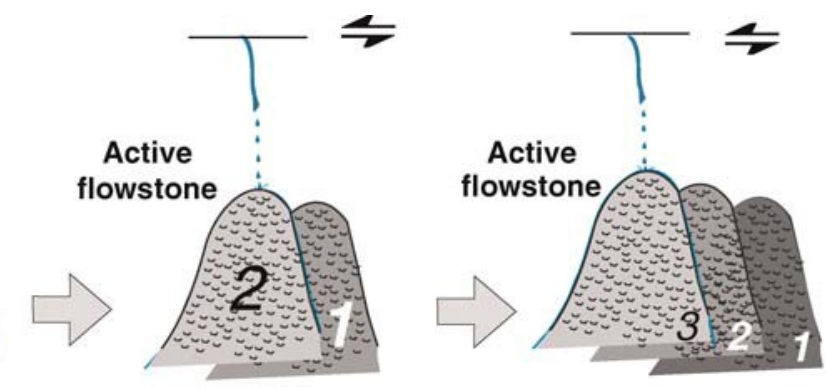

(b)

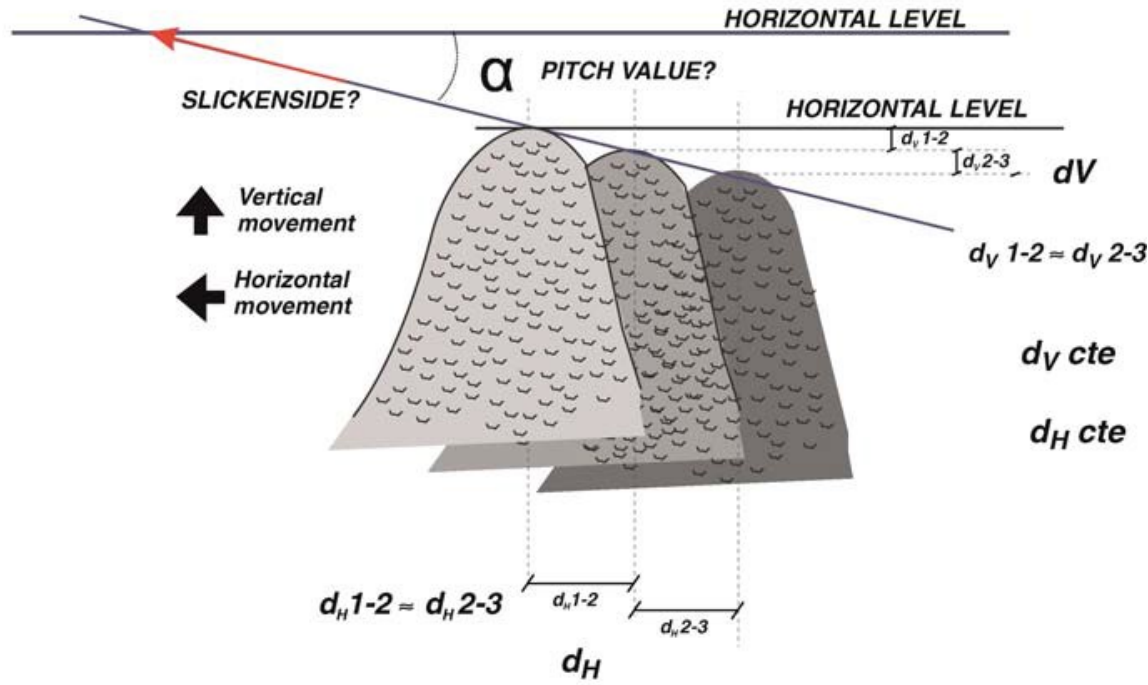

Fig. 7. (a) Front view of the coral pattern and fault plane through time. Vertical and horizontal movements correspond with the relative movements with the roof of the fault plane as the fixed tip. (b) Geometric reconstruction of the theoretical pitch value associated with the migration of the flowstone tip point. See text for further explanation.

The direction of the coral flowstone migration agrees with the rake of the striations on the fault plane estimated above. We measured the averaged vertical and horizontal fault throw, estimated from the apical point migration, at $1.2 \mathrm{~m}$ and $0.8 \mathrm{~m}$ respectively. This means a net fault displacement of $1.44 \mathrm{~m}$, and normal movement with a sinistral strike-slip component (rake $1 / 4588$ ).

\section{Fault population analysis in the cave}

Using the structural data obtained from slickensides we have performed a fault population analysis, in order to determine the strain regime. These slickensides were principally measured on two fault planes, at the Earthquake Hall $(2156 \mathrm{~m})$ and the hanging wall of the Principal Hall (2213 m).

The strain analyses applied here were the slip method (Reches 1983), and the right dihedral method (Angelier \& Mechler 1977). The slip method (SM) allows us to establish the fault plane from both nodal planes (Capote et al. 1991), thus indicating the orientation of the maximum horizontal shortening (ey) of each analysed fault.

Right dihedral (RD) is a qualitative method based on the stereographic projection of areas with similar behaviour, dilatation or compression (Reches 1983). RD analysis indicates the approximate orientation of the main axes of the strain ellipsoid: maximum shortening (ey) and minimum shortening axes (ex).

Figure 8 shows the results obtained for both strain analyses, with ey trending NNW- SSE (Fig. 8a). The right dihedral diagram indicates a strike-slip strain regime with a normal component, compatible with the main orientation of the fault plane of the Principal Hall (NNE-SSW) (Fig. 8b). Accordingly, we have four sinistral strike-slip faults (Fig. 8c), in agreement with the sinistral strike-slip movement interpreted above from the coral growth (Fig. 7), and with similar pitch values. 

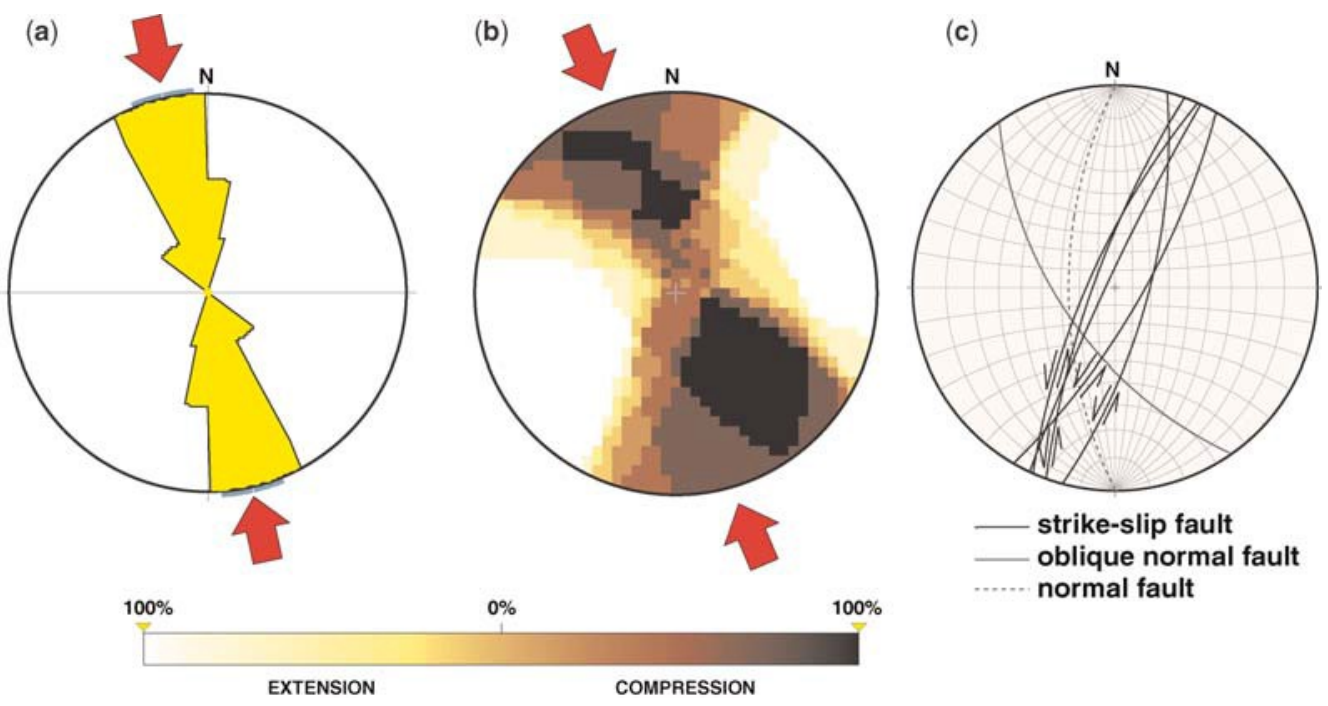

Fig. 8. Right dihedral diagram obtained from the slickensides, measured on fault planes from the Earthquake Hall to the bottom of the cave. This diagram defines a strike-slip strain field with the maximum horizontal shortening (ey) trending NNW-SSE.

\section{Seismotectonics of the Mula earthquake}

The Mula earthquake (2 February 1999) occurred close to the city of Mula and $28 \mathrm{~km}$ SW of Benis Cave (Fig. 9). The estimated magnitude was $\mathrm{m}_{\mathrm{b}} 1 / 44.8$ with MSK intensity of VI-VII (IGN 1999). In the area of the cave the estimated intensity was less than V (Martínez-Díaz et al. 2002). In spite of the low population and infrastructures around the epicentral area, the cost of the damage reached almost 40 million Euros.

The epicentral area is located to the SE of the Betic Cordillera (Fig. 9), an area of moderate to low seismic activity with earthquakes of less than $m_{b} 1 / 45$. Nevertheless, the historic seismicity shows high intensity values such as the Torrevieja earthquake (MSK X) and several earthquakes with MSK close to VIII within the Segura Basin (Mézcua \& Martín-Solares 1983).

Two focal mechanism solutions have been obtained for the Mula seismic crisis, with different interpretations. Firstly, Buforn \& Sanz de Galdeano (2001) obtained a reverse focal mechanism solution for the mainshock and also for the aftershocks (by using seismic wave polarity analysis) (Fig. 9). In contrast, Mancilla et al. (2002) proposed a strikeslip focal mechanism at a depth of $12.5 \mathrm{~km}$, by using the inversion technique of the seismic moment (Fig. 9). The hipocentral depth calculated by the National Geographic Institute of Spain ranged between 4 and $5 \mathrm{~km}$. According to the fault population analyses applied above, our result agrees with the focal mechanism solution of a strike-slip obtained by Mancilla et al. (2002) (Fig. 9).

However, the seismogenic source of the Mula earthquake can only be estimated from the focal mechanisms described above due to its low magnitude. Geological data suggest a possible NE-SW seismogenic source with high dip (B - 708) (Martínez-Díaz et al. 2002). Within the epicentral area several faults with similar strike also show neotectonics evidence (Fig. 9). These faults present geometric features compatible with active segments, able to trigger earthquakes of such a magnitude $\left(\mathrm{m}_{\mathrm{b}} 1 / \mathrm{4}\right.$ 5) (Martínez-Díaz et al. 2002). The epicentral position of the Mula earthquake suggests that the Crevillente Fault could be the seismic source, although the aftershock swarm appears displaced to the SE zone of this fault.

The map of isosist (lines of equal seismic intensity) obtained by Martínez-Díaz et al. (2002) also exhibits a NE-SW elongation. Bejar et al. (2006) carried out a relevant interferometric analysis related to the Mula earthquake, and suggested that it produced a maximum surface deformation of $12 \mathrm{~mm}$. In this sense, these authors proposed a focal mechanism of strike-slip with foci greater than $8 \mathrm{~km}$ in depth, although such strike-slip deformation is difficult to detect using this kind of analysis.

The result obtained from the fault population analysis indicates a sinistral strike-slip sense for NNE- SSW faults. One focal mechanism agrees with this fault character, as described by Mancilla et al. (2002) and other neotectonic evidence for 


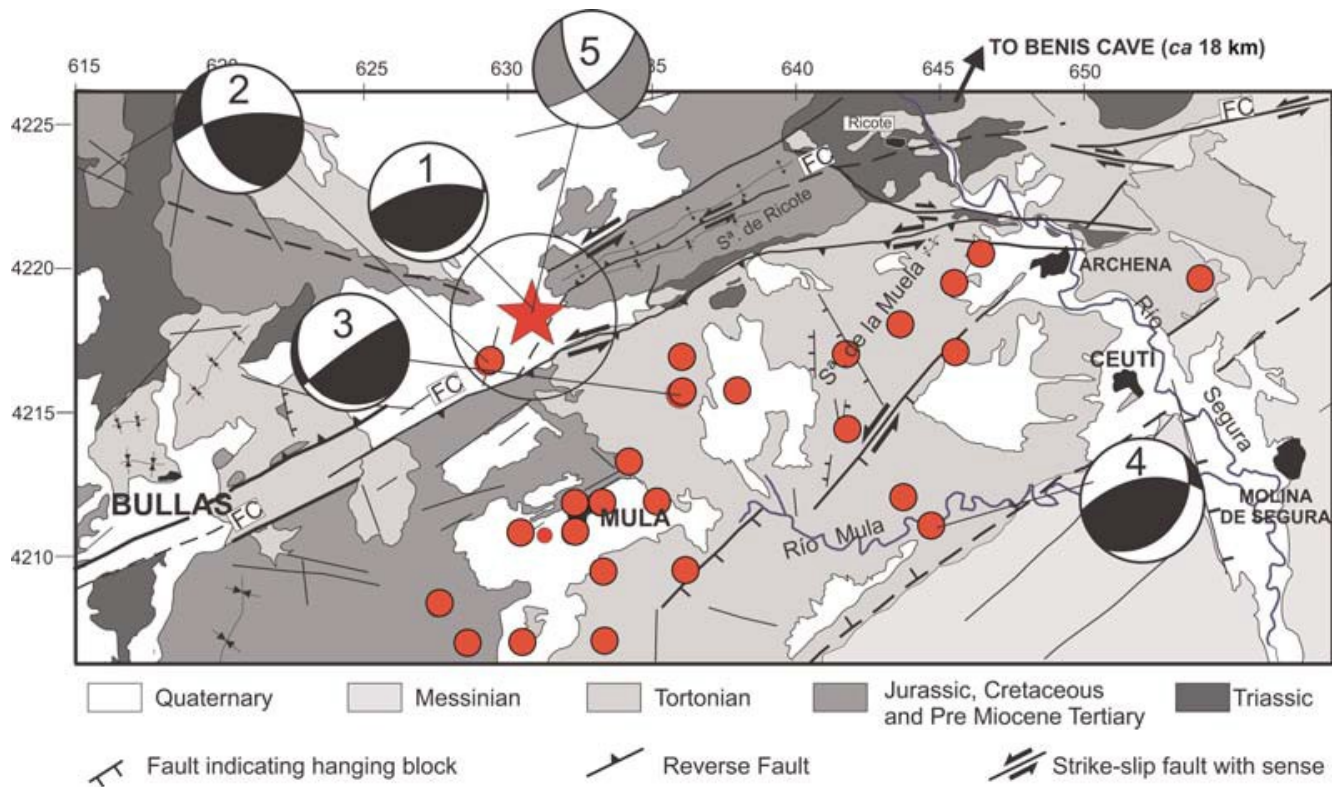

Fig. 9. Seismotectonic sketch of Benis Cave (FC, Crevillente Fault). Focal mechanisms obtained by Buforn \& Sanz de Galdeano (1999): 1, mainshock; 2, 3, 4, aftershocks. The focal mechanism number 5 corresponds to Mancilla et al. (2002) (after Martínez-Díaz et al. 2001).

the area (Silva et al. 1993, 1996; Martínez-Díaz et al. 2002). The palaeoseismic evidence described from the coral flowstone spatial distribution at the bottom of the cave agrees with a dextral strike-slip movement across a fault plane orientated in a NNE-SSW direction (Fig. 9).

\section{Conclusions}

Caves represent a powerful tool as potential palaeoseismic indicators of recent tectonic activity. The present work reports a coseismic rock fall as a consequence of the Mula earthquake $\left(\mathrm{m}_{\mathrm{b}} 1 / 44.8\right.$, MSK VII, 1999). As a result, several blocks of marls collapsed in one small gallery (metre size) at a depth of $2156 \mathrm{~m}$. This represents one of the more severe damaging effects for a deep cave, in relation to an instrumental earthquake, described by a field survey.

We have therefore performed a morphotectonic, structural and palaeoseismic study of Benis Cave. The morphotectonic analysis indicates that the galleries and vertical phreatic tubes developed along an active fault with a NNE-SSW trend. The main galleries, below $2150 \mathrm{~m}$ depth, were determined by the geometry of this fault and the contact between Tertiary limestones and Upper Cretaceous marls.

In addition, a new seismothem is described as a palaeoseismic indicator. The spatial distribution of the coral flowstone (pop-corn) at the bottom of the cave $(2213 \mathrm{~m})$ could be controlled by palaeoearthquake activity. From this pattern growth, two potential palaeoearthquakes showing normal fault movement with dextral strike-slip component were established. By using the Wells \& Coppersmith (1994) empirical relationship for normal seismogenic faults, the palaeoearthquake size corresponds to approximately $6.5, \mathrm{M}, 7 \mathrm{in}$ both cases.

Several fault planes in the cave exhibit slickensides and normal-directional movement grooves. The strain analysis reveals that both the right dihedral diagram and the slip model method are in agreement with the focal mechanism obtained by Mancilla et al. (2002) for the Mula earthquake. These authors obtained a shallow sinistral strikeslip seismic source (15-8 km depth) that is well orientated with respect to the regional stress field defined by Stich et al. (2006).

Nonetheless a more exhaustive work, and numerical dating, is also required in order to establish the complete temporal dynamic of the Quaternary seismicity in the area, although the coseismic block collapse is valuable geological evidence for palaeoseismicity in caves.

We would like to record our sincere thanks to Elisa Kagan and Ives Quinif for their constructive and helpful reviews. Our great thanks also go to Antonio Salmerón, President of the Murcian Speleological Federation of Spain, for 
communicating to us the coseismic effect on Benis Cave a few days after the Mula earthquake (1999). We also thank Eva González, head speleologist, who recently has suffered an awful accident into the Tibia Fresca cave (2500 m, Cantabria), and Emilio Usaola. This work was partially supported by the Spanish Projects of the Ministry of Science and Education ACTISIS, CGL2006-05001/ BTE and TECTO2, CGL2006-28134-E/CLI.

\section{References}

Angelier, J. \& Mechler, P. 1977. Sur une méthode graphique de recherche des contraintes principales également utilisables en tectonique et en sismologie: la méthode des dièdres droits. Bulletin Société Géologique de la France, 9, 1309-1318.

Bauer, S., LiedL, R. \& Sauter, M. 2003. Modelling of karst aquifer genesis: Influence of exchange flow. Water Resources Research, 39(10), 1285-1309.

Becker, A., Davenport, C. A., Eichenberger, U., Gilli, E., Jeannin, P. Y. \& Lacave, C. 2006. Speleoseismology: A critical perspective. Journal of Seismology, 10(3), 371-388.

Bejar, M., Herráiz, E., Martínez-Díaz, J. J., López, C., Capote, R. \& Tsige, M. 2006. Seismotectonic interpretation of the 2002 Mw 4.8 Gérgal seismic sequence using seismological data and RADAR interferometry (InSAR). Geogaceta, 39, 67-70 [in Spanish].

Buforn, E. \& Sanz de Galdeano, C. 2001. Focal Mechanism of Mula (Murcia, Spain) earthquake of February 2, (1999). Journal of Seismology, 5, 277-280.

Cadorin, J. F., Jongmans, D., Plumier, A., CamelBeeck, T., Delaby, S. \& Quinif, Y. 2001. Modelling of speleothems failure in the Hotton Cave (Belgium). Is the failure earthquake induced? Netherlands Journal of Geoscience 80(3-4), 315-321.

Capote, R., De Vicente, G. \& González-Casado, J. M. 1991. An application of the slip model of brittle deformations to focal mechanism analysis in three different plate tectonic situations. Tectonophysics, 191, 339-409.

Delaby, S. 2001. Paleoseismic investigations in Belgium Caves. Cahier du Centre Européen de Geodynamique et de Sismologie, 18, 45-48.

Ferrer, V. 2004. Grandes Cuevas y Simas del Mediterráneo. Editorial Ferrer Rico, Barcelona.

GILLI, E. 2005. Review on the use of natural cave speleothems as palaeoseismic or neotectonics indicators. Geosciencie, 337, 1208-1215.

Gilli, E., Levret, A., Sollogoub, P. \& Delange, P. 1999. Research on the February 18, 1996 earthquake in the caves of Saint-Paul-de-Fenouillet area (eastern Pyrenees, France). Geodinamica Acta, 12(3-4), $143-158$.
IGN. 1999. Serie sísmica de Mula (Murcia). Segundo Informe General. Edita Subdirección General de Geodesia y Geofísica. Madrid.

Jerez Mir, L., Jerez Mir, J. \& García-Monzón, G. 1972. Mapa geológico de España E. 1:50.000. Serie MAGNA (IGME). Hoja de Mula, 912.

Kagan, E. J., Agnon, A., Bar-Matthews, M. \& Ayalon, A. 2005. Dating large, infrequent earthquakes by damaged cave deposits. Geology, 33(4), 261-264.

Mancilla, F. L., Ammon, C. J., Herrmann, R. B. \& Morales, J. 2002. Faulting parameters of the 1999 Mula Earthquake, Southeastern Spain. Tectonophysics, 354, 139-155.

Martínez-Díaz, J. J., Masana, E., HernándezEnrile, J. L. \& Santanach, P. 2001. Evidence for co-seismic events of recurrent prehistoric deformation along the Alhama de Murcia fault, southeastern Spain. Monografía: Paleosismicidad en España. Acta Geológica Hispánica, 36(3-4), 315-327.

Martínez-Díaz, J. J., Rigo, A., Louis, L., Capote, R., Hernández-Enrile, J. L., Carreño, E. \& Tsige, M. 2002. Caracterización geológica y sismotectónica del terremoto de Mula (febrero de 1999, Mb:4,8) mediante la utilización de datos geológicos, sismológicos y de interferometría de RADAR (INSAR). Boletín Geológico y Minero 113(1), 23-33.

Mézcua, J. \& Martínez-Solares, J. M. 1983. Sismicidad del área Ibero-Magrebí. Instituto Geográfico Nacional. Madrid.

Postpischl, D., Agostini, S., Forti, P. \& Quinif, Y. 1991. Palaeoseismicity from karst sediment: the "Grotta del Cervo" cave case study (Central Italy). Tectonophysics, 193, 33-44.

Reches, Z. 1983. Faulting of rocks in three-dimensional strain fields, II. Theoretical analysis. Tectonophysics, 95, 133-156.

Silva, P. G., Goy, J. L., Somoza, L., Zazo, C. \& BARDAJí, T. 1993. Landscape response to strikeslip faulting linked to collisional settings: Quaternary tectonics and basin formation in the Eastern Betics, Southeast Spain. Tectonophysics, 224, 289-303.

Silva, J. P., Mather, J. L., Goy, J. L., Zazo, C. \& Harvey, A. M. 1996. Controles en el desarrollo y evolución del drenaje en zonas tectónicamente activas: el caso del río Mula (Región de Murcia, SE España). Revista de la Sociedad Geológica de España, 9(3-4), 269-285.

Stich, D., Serpelloni, E., Mancilla, F. L. \& Morales, J. 2006. Kinematics of the IberiaMaghreb plate contact from seismic moment tensors and GPS observations. Tectonophysics, 426(3-4), 295-317.

Wells, D. L. \& Coppersmith, K. J. 1994. New empirical relationships among magnitude, rupture length, rupture width, rupture area, and surface displacement. Bulletin of the Seismological Society of America, 84(4), 974-1002. 